\title{
Perkembangan morfologi kawasan Kota Lama Kupang
}

\section{Rudini A. R. B. Lamahoda}

Program Studi Magister Arsitektur, Program Pascasarjana, Universitas Atma Jaya Yogyakarta, Indonesia, rudialvian21@gmail.com

\section{Amos Setiadi}

Program Studi Arsitektur, Fakultas Teknik, Universitas Atma Jaya Yogyakarta, Indonesia amos.setiadi@uajy.ac.id

\section{Reginaldo Christophori Lake}

Program Studi Arsitektur, Fakultas Teknik, Universitas Katolik Widya Mandira, Kupang, Indonesia, reginaldolake@unwira.ac.id

\section{Ricky Samara,}

Program Studi Arsitektur, Fakultas Teknik, Universitas Katolik Widya Mandira, Kupang, egilake15@gmail.com

\begin{abstract}
Abstrak
Kota Kupang adalah Ibu Kota Provinsi Nusa Tenggara Timur, terletak di pesisir Teluk Kupang, bagian Barat Laut Pulau Timor. Perkembangan kawasan Kota Lama Kupang dimulai pada periode abad ke-15, diawali sebagai kota bandar yang dikuasi oleh Raja Helong hingga adanya intervensi pemerintahan Belanda, Portugis, dan Cina, sehingga memiliki morfologi kawasan kota yang unik untuk diteliti. Tujuan penelitian ini ialah mengidentifikasi perkembangan kawasan Kota Lama Kupang selama beberapa periode dan menganalisis perubahan serta perbandingan apa saja terkait morfologi kawasan Kota Lama Kupang. Penelitian deskriptif eksploratif dengan metode analisis sinkronik (tissue analysis) digunakan dalam penelitian ini untuk membaca sejarah yang terjadi pada kawasan Kota Lama Kupang dari periode awal terbentuk kawasan yakni abad ke-15 sampai pada abad ke21. Selanjutnya, metode analisis diakronik (historical reading) digunakan untuk menemukan perubahan serta perbandingan morfologi kawasan Kota Lama Kupang periode abad ke-15 sampai abad ke-21 dan memaparkan bagaimana ruang-ruang Kota Lama Kupang mulai bertumbuh serta berkembang. Penelitian ini menghasilkan kesimpulan bahwa kawasan Kota Lama Kupang mulai berkembang karena memiliki generator utama yaitu masuknya kekuasaan Raja Helong untuk menjadikan Kota Lama Kupang sebagai kota bandar yang ada di Pulau Timor. Temuan perubahan dan perbandingan perkembangan morfologi kawasan Kota Lama Kupang ialah saat masuknya bangsa Belanda, Portugis, dan etnis Cina serta terjadi perubahan setelah Indonesia merdeka yakni perubahan status kawasan Kota Lama Kupang berdasakan aspek politik yang berkembang.
\end{abstract}

Kata kunci: kawasan Kota Lama Kupang, kota bandar, morfologi kota,ruang-ruang Kota Lama

\begin{abstract}
Kupang is the capital of East Nusa Tenggara Province, located on the coast of Kupang Bay, northwest of Timor Island. The development of Kupang old city area began in the 15th century, starting as a city initiated by King Helong until the Dutch, Portuguese, and Chinese governments' intervention. It has a unique morphology of the city area to research. The purpose of this study is to identify the development of the Kupang Old City area over several periods and analyze any changes and comparisons related to the morphology of the Kupang Old City area. Exploratory, descriptive research with tissue analysis method is used in this study to read the history that occurred in Kupang old city area from the early period formed the 15th-century area until the 21st century. Furthermore, the historical reading method was used to find changes and morphological comparisons of the Kupang Old City area from the 15th to
\end{abstract}


the 21st century and explain how Kupang old city spaces began to grow and develop. This research concluded that the Kupang old city area began to develop because it has the foremost generator that is the entry of King Helong's power to make Kupang Old City a city on Timor Island. The findings of changes and comparisons of the morphological development of Kupang Old City area are due to the influx of Dutch, Portuguese, and ethnic Chinese, and there is a change after Indonesia's independence, namely the change in the status of Kupang old city area based on the evolving political aspects

Keywords: Kupang old town area, trading city, city morphology old town spaces,

Received: 2020-08-23 | Accepted: 2020-10-24 | DOI: 10.29080/eija.v6i2.1010| Page: 77-90

EMARA: Indonesian Journal of Architecture

http://jurnalsaintek.uinsby.ac.id/index.php/EIJA

(1) This article is open access distributed under the terms of the Creative Commons Attribution ShareAlike 4.0 International License, which permits unrestricted use, distribution, and

reproduction in any medium provided the original work is properly cited.

\section{Pendahuluan}

Morfologi merupakan suatu artefak dalam sebuah kota (urban artefac) yang menggambarkan proses perkembangan kota melalui artefak-artefak yang terjadi pada suatu kawasan (Rossi, 1984). Menurut Whitehand (1977), kajian mengenai sejarah suatu kota merupakan dasar yang sangat penting dalam melakukan kajian morfologi suatu kota yang di dalamnya memiliki karakter fisik perkotaan berupa perubahan yang terjadi dari waktu ke waktu dan menjadi penilaian di masa yang akan datang dalam konsep desain perkotaan (Whitehand, 1977).

Fenomena morfologi kota-kota di Indonesia pada umumnya memiliki perkembangan yang berbeda-beda, baik itu karakteristik geografis, sejarah, perekonomian, dan sosial budaya masyarakat (Setiadi, 2018). Proses perkembangan kota tentunya mempunyai proses yang panjang, sebab ditentukan oleh pelbagai faktor penting yang terjadi (Ardhiansyah et al., 2019).

Kota Kupang sebagai objek studi dari penelitian ini memiliki sejarah yang cukup panjang jika dilihat dari masa-masa terbentuknya kota. Kota Kupang sebagai kota terbesar di Provinsi Nusa Tenggara Timur, didiami oleh pelbagai suku bangsa. Suku yang signifikan jumlahnya di Kota
Kupang adalah suku Timor, Rote, Sabu, Tionghoa, Flores dan sebagian kecil pendatang dari Bugis, Jawa dan Arab (Lake et al., 2019).

Awal perkembangan Kota Kupang berasal dari kawasan Kota Lama Kupang yang sekarang sudah menjadi sebuah kelurahan yang dikenal dengan Lahi Lai Bissin Kopan (LLBK). Kelurahan Lahi Lai Bissin Kopan berada di pantai teluk Kupang atau terminal Kota Lama Kupang (Lihat gambar 1).

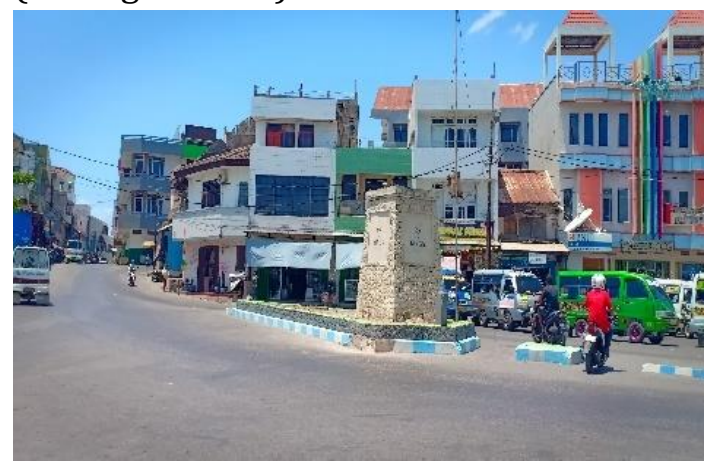

Gambar 1. Terminal Kota Lama Kupang, Kelurahan Lahi Lai Bissin Kopan (LLBK) (dokumentasi peneliti, 2019)

Terbentuknya kawasan Kota Lama Kupang dimulai dengan kedatangan bangsa Portugis dan Belanda pada awal abad 16 untuk menguasai Kota Kupang. Bangsa Portugis pertama menginjakan kaki di Kupang pada tahun 1645 dan mendirikan sebuah benteng. Kemudian, terjadi perselisihan diantara bangsa 
Portugis sendiri, sehingga benteng tersebut ditinggalkan. Di tahun 1653 bangsa Belanda datang dan merebut benteng Portugis tanpa ada paksaan. Selama berkuasa, bangsa Belanda mempunyai pengaruh yang cukup besar dalam perkembangan Kota Lama Kupang, yakni perkembangan pada infrastruktur, ekonomi, sosial, dan politik (Departemen Pendidikan dan Kebudayaan Republik Indonesia, 1983).

Selama Belanda berkuasa, pada tahun 1655 terjadi krisis makanan di kawasan Kota Kupang akibat terjadi peperangan antara Portugis yang bersekutu dengan raja pedalam di Timor untuk mengusir Belanda. Oleh karena itu, Belanda mendatangkan etnis Cina untuk membawa pasokan makanan dari luar(Situmorang, 2018) (Lihat gambar 2 bekas pelabuhan utama kawasan Kota Lama Kupang sebagai pintu masuk bangsa asing).

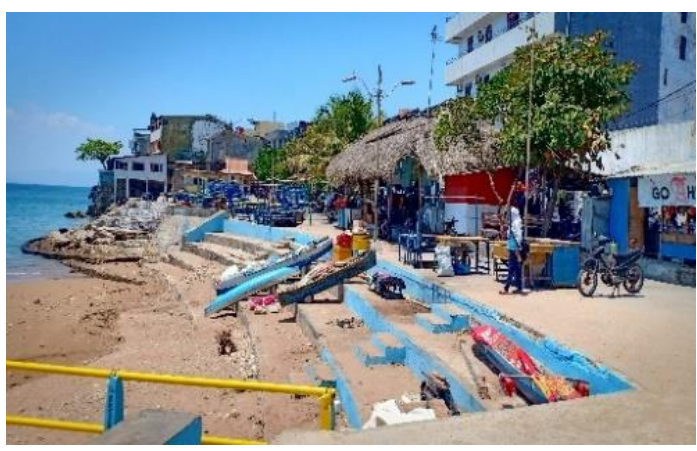

Gambar 2. Bekas pelabuhan Kota Lama Kupang, Kelurahan Lahi Lai Bissin Kopan (LLBK) (dokumentasi peneliti, 2019)

Di periode abad ke 17 Belanda mulai membangun beberapa bangunan dan pemukiman bagi sekutu-sekutunya. Kemudian di periode abad ke 18 terdapat kejadian penting yaitu Belanda menetapkan batas-batas kota untuk menyangga kawasan Kota Lama Kupang. Penetapan batas kota tersebut terjadi perluasan jaringan jalan dan penambahan pemukiman(Departemen Pendidikan dan Kebudayaan Republik Indonesia, 1983; Situmorang, 2018).
Periode abad ke 19 perkembangan kawasan lebih dominan ke arah pembangunan yaitu perluasan jaringan jalan sampai di luar kawasan Kota Lama Kupang, penambahan bangunan dan peningkatan status kawasan Kota Lama Kupang menjadi Kota Madya Kupang (Lihat gambar 3). Pada abad ke 21 kawasan Kota Lama Kupang terus berkembang mulai dari penambahan bangunan serta penambahan pemukiman (Departemen Pendidikan dan Kebudayaan Sejarah dan Nilai Tradisional, 1983).

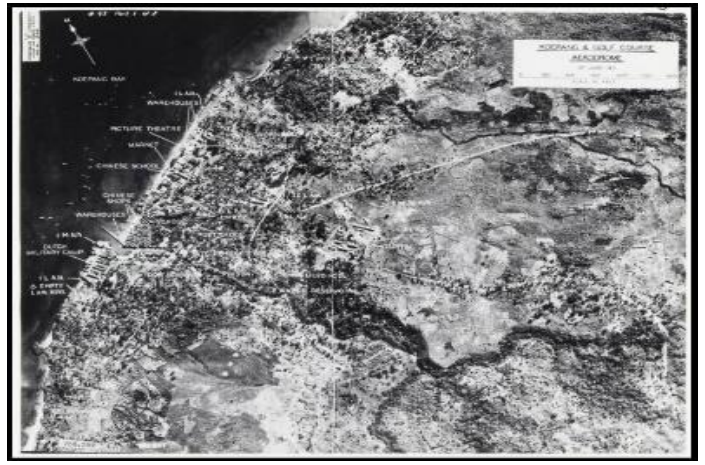

Gambar 3. Foto udara kawasan Kota Lama Kupang tahun 1943 (Sumber: (Bakosurtanal, 1998)

Perubahan fisik ruang kota tidak terjadi secara abstrak, langsung, dan secara otomatis, melainkan dipengaruhi proses dimensi waktu yang cukup lama, dan manusia sebagai pelaku utama. (Bintarto, 1977; Zahnd, 1999) (Yunus, 2008) menyatakan perubahan fisik ruang tersebut dapat ditinjau dengan perkembangan kota melalui pendekatan morfologi kota (urban morphological approach)(Yunus, 2008).

Berdasarkan sejarah singkat yang telah dipaparkan, kawasan Kota Lama Kupang selama beberapa periode mengalami perkembangan yang cukup panjang. Oleh sebab itu, penelitian ini mencoba mengkaji tentang perkembangan kawasan Kota Lama Kupang berdasarkan sejarah kawasan, dan menganalisis perubahan serta perbandingan morfologinya dari periode abad ke 15,16 , 17, 18, 19, dan 21. Lokasi penelitian 
berada di Kelurahan Lahi Lai Bissin Kopan (LLBK) Kecamatan Kota Lama Kupang, Kota Kupang, Provinsi Nusa Tenggara Timur (NTT)

\section{Metode}

Penelitian morfologi kawasan Kota Lama Kupang menggunakan dua metode analisis yakni metode sinkronik (tissue analysis) dan diakronik (historical reading). Metode sinkronik (tissue analysis) digunakan untuk membaca sejarah perkembangan kawasan Kota Lama Kupang pada beberapa periode waktu atau pada abad ke 15 awal terbentuk sampai pada abad ke 21.

Dalam beberapa periode tersebut lebih ditekankan pada kejadian-kejadian penting di setiap periode abad yang berpengaruh terhadap aspek fisik berupa terbangunnya jalan, bangunan dan aspek nonfisik berupa pengaruh ekonomi, sosial, politik terhadap perkembangan kawasan Kota Lama Kupang berdasarkan sejarah dan fakta-fakta sejarah yang terjadi. Kemudian, analisis diakronik (historical reading) digunakan untuk melihat perubahan dan perbandingan perkembangan morfologi kawasan Kota Lama Kupang periode abad ke 15 sampai abad ke 21, serta memaparkan bagaimana ruang-ruang kawasan Kota Lama Kupang mulai bertumbuh, dan berkembang.

$$
\text { Untuk memperkuat }
$$

perbandingannya maka digunakan metode superimpose yakni menumang tindihkan (overlay) peta berdasarkan beberapa periode. Pada penggambaran peta sesuai dengan analisis sinkronik, maka digunakan peta tahun 1900 sebagai dasar acuan dalam menggambarkan periode sebelumnya yaitu periode 1500 , 1600, 1700, 1800 dan periode sesudah yaitu periode 1900, 2000, 2019. Kemudian, berdasarkan analisis sinkronik dan diakronik akan diketahui bagaimana perkembangan kawasan Kota Lama
Kupang, bagaimana perubahan serta perbandingan perkembangan morfologi kawasan Kota Lama Kupang, sehingga akan didapatkan faktor yang memengaruhi perkembangan morfologi kawasan dari periode abad ke 15 sampai abad ke 21.

Analisis faktor yang mempengaruhi perkembangan kawasan Kota Lama Kupang menggunakan teori (Branch, 1995) yaitu proses perkembangan sebuah kota akan disesuaikan dengan perkembangan di dalam masyarakat maupun pelbagai sumber daya pendukungnya (Branch, 1995). Hasil analisis akan diinterpretasikan sesuai tujuan penelitian yaitu membaca perubahan, dan perbandingan perkembangan morfologi Kota Lama Kupang.

\section{Kasus studi}

Kota Lama Kupang adalah salah satu Kecamatan dari 6 (enam) Kecamatan yang ada di wilayah Pemerintah Kota Kupang dengan luas wilayah $3,22 \mathrm{~km}^{2}$ serta terbagi dalam 10 (sepuluh) Kelurahan (BPS Kota Kupang, 2014). Posisi Kecamatan Kota Lama Kupang sangat strategis yakni terletak di tengah jantung Kota Kupang, dan pusat perdagangan atau jasa, serta terletak pada titik koordinat 1009'31.4" Lintas Selatan 12335'36.0" Bujur Timur, dengan batas-batas wilayah administrasi sebagai berikut: (1) Sebelah Utara berbatasan dengan Teluk Kupang; (2) Sebelah Selatan berbatasan dengan Kecamatan Oebobo; (3) Sebelah Timur berbatasan dengan Kecamatan Kelapa Lima; dan (4) Sebelah Barat berbatasan dengan Kecamatan Alak (Badan Pusat Statistik, 2014) (Lihat gambar 4). 


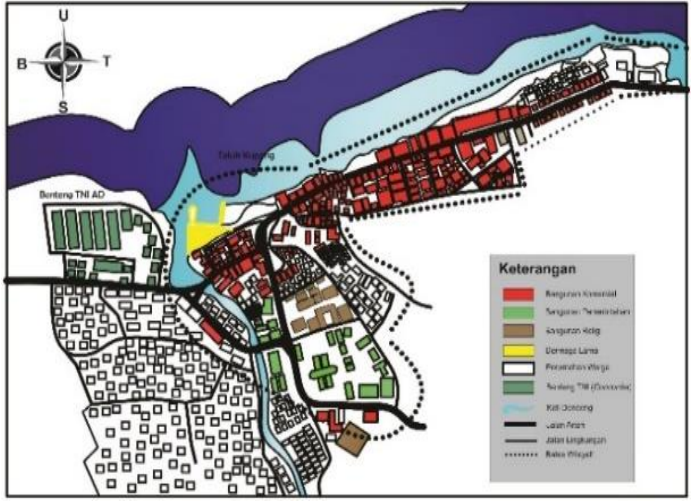

Gambar 4. Peta Kota Lama Kupang tahun 2019 (analisis peneliti, 2019)

\section{Hasil dan Pembahasan}

\section{Sejarah kawasan Kota Lama Kupang}

Kota Kupang semula merupakan tempat tinggal orang Helong, Raja Helong (di sebut Koepan) berkedudukan di lokasi yang bernama Kai Salun (daerah Fatufeto) dan Buni Baun (daerah Lahi-lai Bissi Kopan). Pemukiman-pemukiman yang ada merupakan milik Raja Helong yang letaknya tersebar di sekitar muara sungai Kupang (Kali Dendeng, dan Sungai Airmata) (Lake et al., 2019, 2019; Luitnan, 2012).

Kedatangan Belanda ditandai dengan kehadiran benteng Concordia. Benteng Concordia dibangun oleh Belanda sebagai tempat tinggal aparat pemerintah dan pasukan Belanda, Tahun 1653 Kota Lama Kupang sudah ditempati orangorang Solor, sebelum kedatangan Belanda. Saat Belanda memerintah dengan kedudukannya di benteng Concordia selalu mendapat ancaman dari Portugis/Topasses yang bersekutu dengan beberapa raja pedalaman di Pulau Timor. Untuk mempertahankan kedudukannya Belanda harus memperkuat pasukan yang terdiri para orang kulit putih (Belanda), orang Solor, orang Rote, orang Sabu, dan orang Mardykers. Usaha menambah kekuatan pasukan tersebut juga di perlukan untuk menaklukan Raja-raja yang ada di Pulau Timor dan sekitarnya (Departemen
Pendidikan dan Kebudayaan Republik Indonesia, 1983). Strategi Belanda menambah pasukan menjadikan benteng Concordia tidak dapat menampung seluruh pasukan. Sehingga, anggotaanggota pasukan dan tenaga penunjang yang terdiri dari para budak, harus di tempatkan di luar benteng. Penempatan pasukan tersebut diatur berdasarkan kelompok etnis, maka muncul tempattempat pemukiman di luar benteng sebagai tempat tinggal orang-orang Rote, orang Sabu, orang Solor, orang Madykers, para budak, dan orang Kupang (Helong) (Detaq, 1971). Sejak terciptanya kelompok-kelompok pemukiman di luar benteng, bangsa Portugis/Topases dengan mudah menyerang sekutu-sekutu Belanda, sehingga tempat tinggal orang Helong akhirnya bergeser ke Pulau Semau (Luitnan, 2012).

Pada periode awal abad ke 18, para prajurit Belanda yang berasal dari golongan pribumi disediakan tempat tinggal yang berbeda. Satu wilayah tempat tinggal disediakan untuk penduduk campuran yakni budak-budak yang telah merdeka, disebut orang Mardykers. Satu lagi ialah wilayah khusus disediakan bagi para prajurit yang berasal dari Pulau Rote, dan Pulau Sabu (Fox, 1997). Pada periode awal abad ke 19 terdapat satu golongan prajurit Belanda yang disebut papangers, yakni para prajurit yang berasal dari keturunan Philipina. Prajurit papangers umumnya beragama Islam. Semula orang Spanyol yang menggunakan tempat prajurit papangers, kemudian Belanda juga menggunakan tempat tinggal para papangers, Belanda memberikan hadiah tanah sebagai tempat koloni kepada orang Spanyol, seperti prajurit-prajurit pribumi yang lainnya (Fox, 1997). Namun, sampai abad ke 17 dan 18 Kota Kupang sebagai sebuah pusat kegiatan Belanda dan 
sebagai kota benteng belum mempunyai batas-batas wilayah yang jelas.

Semakin banyak anggota-anggota pasukan Belanda dan sekutu-sekutunya yang berada di Kota Kupang dan sekitarnya, penyediaan bahan makanan menjadi masalah yang serius. Raja-raja di daerah pedalaman terus melakukan perlawanan terhadap Belanda. Daerahdaerah subur di sekitar Kota Kupang kosong karena penduduknya mengungsi akibat serangan Portugis. Dengan demikian, bahan makanan sepenuhnya bergantung dari luar. Untuk mendatangkan beras dari luar, Belanda memerlukan jasa orang Cina. Oleh karena itu di Kota Kupang berkembang kediaman Cina di sekitar pantai dekat benteng di tempat yang nantinya berkembang menjadi kampung Cina (Lahi-Lai bessi Kopan)(Departemen Pendidikan dan Kebudayaan Republik Indonesia, 1983).

Untuk kepentingan keamanan dan pemenuhan pangan, maka oleh Belanda telah diatur tempat tinggal di luar benteng sebagai penyangga. Anggota pasukan diharapkan dapat bercocok tanam sendiri dengan bantuan tenaga budak di luar pusat kota. Untuk memperluas daerah produksi, dan sumber tenaga pasukan, Belanda mulai memindahkan orang-orang dari Pulau Rote dan membentuk daerah kolonisasi di Babau dan Pariti (Departemen Pendidikan dan Kebudayaan Republik Indonesia, 1983)

Atas pertimbangan kepentingan keamanan bagi pusat pemerintahan Belanda. Residen Greeve memohon kepada Gubernemen Hindia Belanda, agar menetapkan batas-batas Kota Kupang (Departemen Pendidikan dan Kebudayaan Republik Indonesia, 1983; Luitnan, 2012). Saat Belanda mendirikan daerah penyangga di sekitar teluk Kupang dengan cara mendirikan kolonisasi dari golongan etnis Rote yang dipindahkan ke sekitar teluk Kupang, daerah tersebut akhirnya juga berfungsi sebagai penunjang pemenuhan kebutuhan bahan makanan di Kota Kupang. Hal tersebut diharapkan mengurangi ketergantungan Kota Kupang terhadap pemenuhan bahan makanan dari luar. Sehingga, peristiwa tahun 1665 Kota Kupang terisolir akibat tidak datangnya kapal dan bahan makanan.

Pada periode abad ke 18 tanggal 25 April 1886 dengan lembaran negara no. 171 tahun 1886, Residen Greeve menetapkan batas-batas kota yang disebut 'Vierkante paal gabied'. Adapun batasbatas Kota Kupang yakni sebelah Barat ke arah tenau sampai kampung Nun Hila; sebelah Timur ke arah pasir panjang batas sampai di dekat kantor sinode GMIT. Sebelah Selatan ke arah Air Mata sampai di jembatan gantung (daerah Mantasi). Wilayah Kota Kupang saat itu disebut 'Rechts treek Bestuurs gebied' yakni pemerintah daerah (salah satu bentuk birokrasi pemerintah pada masa Hindia Belanda) meliputi Desa Fatufeto, Nun Hila, airmata, Fontein, Solor, Tode Kisar, dan Oeba (Departemen Pendidikan dan Kebudayaan Republik Indonesia, 1983).

Disamping desa-desa tersebut sebagai pusat pemukiman, benteng Concordia merupakan pusat pertahanan. Pelabuhan Kupang yang terletak di muara sungai Kupang dekat benteng Concordia dan daerah pantai di antara pelabuhan dan Kampung Solor merupakan pusat perdagangan dan daerah di pinggir sungai Kupang disebut herenstraat yakni pusat pemerintahan dan kediaman Belanda (Departemen Pendidikan dan Kebudayaan Republik Indonesia, 1983).

Pada abad ke 19 atau tahun 1900 kawasan Kota Lama Kupang bertumbuh pesat akibat pembangunan bangunanbangunan, perluasan jaringan jalan, dan pemukiman-pemukiman masyarakat yang 
mulai dibangun oleh Belanda (Lihat gambar 5).

Kota Kupang di tahun 1953 berstatus disamakan dengan Kecamatan dan mempunyai luas wilayah $3.72 \mathrm{~km} 2$, yang meliputi 11 buah Desa, yaitu Desa Nunbaun Delha, Nunhila, Fatufeto, Mantasi, Airmata, Fontein, Bonipoi, Solor, Merdeka, Oetete dan Oeba(Departemen Pendidikan dan Kebudayaan Republik Indonesia, 1983) .

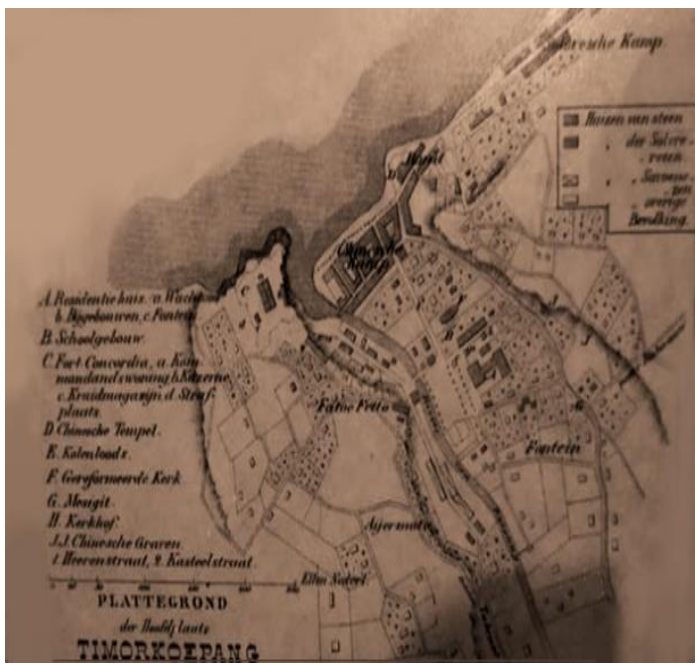

Gambar 5. Peta Kawasan Kota Lama Kupang tahun 1900 (jejakembara, 2014)

Tahun 1969 Kota Kupang resmi berstatus sebagai Kecamatan Kota Kupang dengan luas wilayah $22.59 \mathrm{~km} 2$. Dengan demikian, luas wilayah Kota Kupang mengalami kenaikan 507\%. Naiknya luas wilayah yang menyolok selama 13 tahun disebabkan bertambahnya jumlah desa yang masuk dalam wilayah Kota Kupang. Sebelumnya jumlah desa hanya 11, kemudian pemekaran menjadi 24 desa. Jadi, jumlah desa naik 118\%. Desa-desa yang masuk wilayah Kota Kupang adalah Airnona, Airmata, Bakunase, Fontein, Kuanino, Mantasi, Naikoten I, Pasir Panjang, Oeba, Merdeka, Tode kisar, Solor, Bonipoi, Lahi lai Besi Kopan, Fatufeto, Nunhila, Nunbaun delha, Nunbaun Sabu dan Namosain.

\section{Kondsi kawasan Kota Lama Kupang masa sekarang (2019)}

Perkembangan kawasan Kota Lama Kupang khususnya area Kelurahan Lahi Lai Bissin Kopan (LLBK) menjadi kawasan pusat perdagangan yang didominasi oleh orang Tionghoa dan para pendatang dari wilayah Arab, Bugis serta orang-orang asli pribumi yaitu orang Solor, Rote dan Sabu. Kemudian pada area pemukiman di kawasan Kota Lama Kupang ditata lebih teratur dari periode-periode sebelumnya. Kawasan Kota Lama Kupang juga ditetapkan sebagai kawasan perdagangan dan jasa yang diatur dalam pembagian Rencana Tata Ruang Wilayah (RTRW) 2011-2031.

Permukiman kawasan Kota Lama Kupang pada masa sekarang mempunyai batas-batas wilayah yang ditetapkan oleh pemerintah dan berstatus sebagai Kecamatan Kota Lama yang sudah mekar dan terbagi menjadi 10 kelurahan yakni: Kelurahan Pasir Panjang, Kelurahan Oeba, Kelurahan Nefonaek, Kelurahan Airmata, kelurahan Merdeka, Kelurahan Fatubesi, Kelurahan LLBK, Kelurahan Tode Kisar, Kelurahan Solor, dan Kelurahan Bonipoi. Khususnya Kelurahan Lahi lai Bissin Kopan (LLBK) pada zaman kolonial merupakan tempat tinggal Raja Helong dan menjadi pusat pemerintahan Belanda, sekarang menjadi sebuah kelurahan.

Periode abad ke 21, beberapa bekas bangunan peninggalan Belanda tidak difungsikan dan beberapa lainnya dialih fungsikan. Pelabuhan laut atau dermaga Kota Lama Kupang sudah dialih fungsikan sebagai pelabuhan bagi para wisatawan luar negeri yang berwisata di Kota Kupang untuk berlabuhkan kapalkapal wisatawan. Di area sekitaran pelabuhan dijadikan sebagai tempat berdagang oleh pedagan kaki lima (PKL), bar, penginapan, dan pertokoan 


\section{Acuan dalam menganalisis perkembangan morfologi kawasan Kota Lama Kupang}

Analisis penelitian menggunakan peta kawasan Kota Lama Kupang tahun 1900 sebagai acuan untuk menggambarkan peta periode sebelumnya ialah periode 1500 , $1600,1700,1800$ dan periode sesudahnya ialah periode 1900, 2019. Analisis beberapa periode lebih ditekankan pada kejadian-kejadian penting yakni terbangunnya elemen-elemen fisik kawasan Kota Lama Kupang berupa jalan, blok, guna lahan dan bangunan, berdasarkan fakta-fakta sejarah yang terjadi pada perkembangan kawasan Kota Lama Kupang.

\section{Analisis sinkronik kawasan Kota Lama} Kupang periode abad ke 15 - 21

Periode Abad ke 15

Berdasarkan sejarah perkembangan kawasan Kota Lama Kupang dapat dianalisis perkembangan kawasan Kota Lama kupang pada periode abad ke 15 sampai abad ke 21 pada peta berikut ini (Lihat gambar 6).

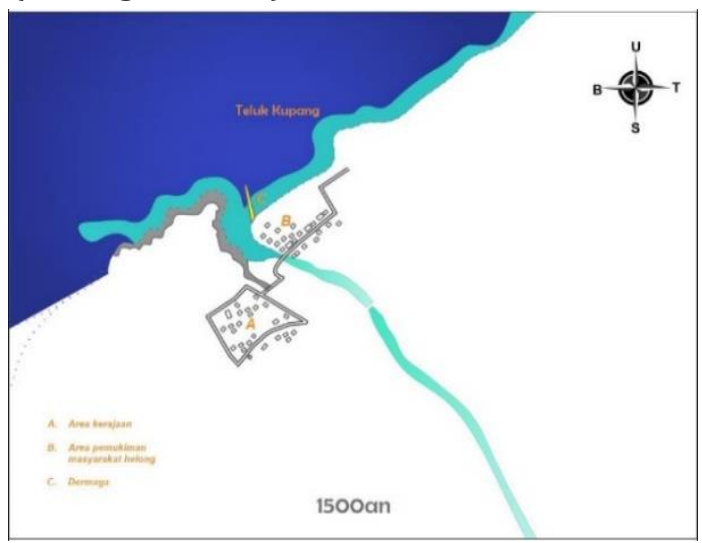

Gambar 6. Peta kawasan Kota Lama Kupang abad ke 15.(analisis peneliti, 2019)

Periode Abad ke 16

Periode abad ke 16 dipengaruhi oleh kedatangannya bangsa Portugis, Belanda dan Cina. Secara signifikan periode abad ke 16 Kota Lama Kupang terjadi perkembangan jaringan jalan ke arah Timur permukiman orang Solor dan ke arah Barat menuju benteng Concordia.
Akibat perkembangan dan perpanjangan akses jalan maka muncul blok-blok kawasan di area permukiman orang Solor seperti permukiman masyarakat bangsa Cina (Lihat gambar 7 dan gambar 8).

Temuan hasil analisis sinkronik perkembangan kawasan Kota Lama Kupang periode abad ke 16

Berdasarkan hasil analisis sinkronik perkembangan kawasan Kota Lama Kupang maka didapatkan temuan sebagai berikut: (1) Masuknya bangsa Portugis dan diberi tanah oleh Raja Helong, maka Portugis membangun benteng pertama di Teluk Kupang; (2) Masuknya Bangsa Belanda bekas benteng Portugis direbut dan diberi nama 'Fort Concordia'; (3) Masuknya etnis Cina dibangunnya camp Cina oleh Belanda di area Teluk Kupang yang berhadapan langsung dengan pelabuhan Teluk Kupang.; (4) Kedatangan ketiga bangsa tersebut menciptakan penambahan elemen jaringan jalan yang menghubungkan benteng, pelabuhan dan pemukiman pada kawasan Kota Lama Kupang serta pembangunan kuil Cina dekat Teluk Kupang; (5) Kawasan Kota Lama Kupang mulai tumbuh menjadi pusat ekonomi karena adanya kegiatan perdagangan.

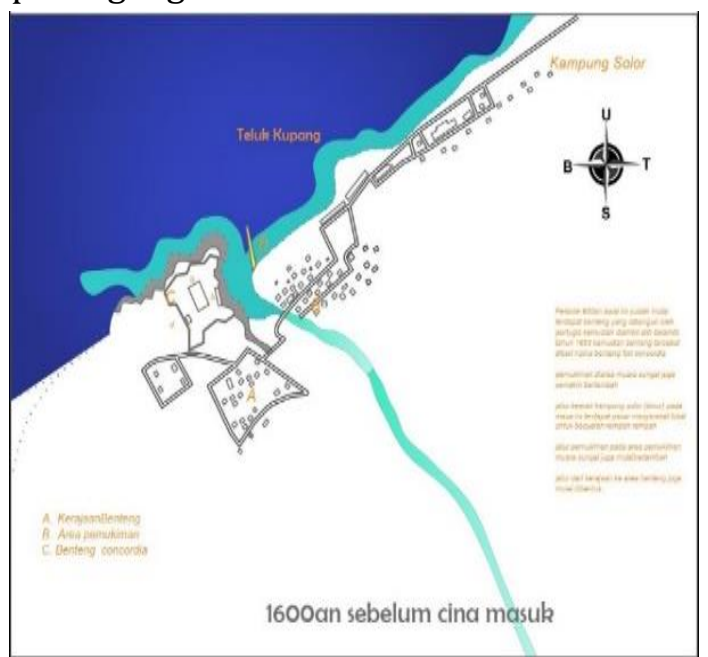

Gambar 7. Peta kawasan Kota Lama Kupang abad ke 16, kedatangan bangsa Portugis dan Belanda (analisis peneliti, 2019) 


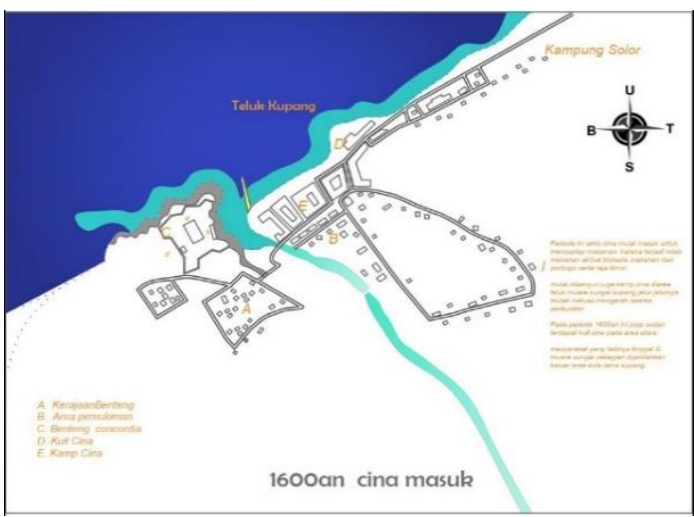

Gambar 8. Peta kawasan Kota Lama Kupang abad ke 16, kedatangan bangsa Cina (analisis peneliti, 2019)

\section{Periode Abad ke 17}

Perkembangan Kota Lama Kupang pada periode abad ke 17 dapat dilihat pada gambar 9.

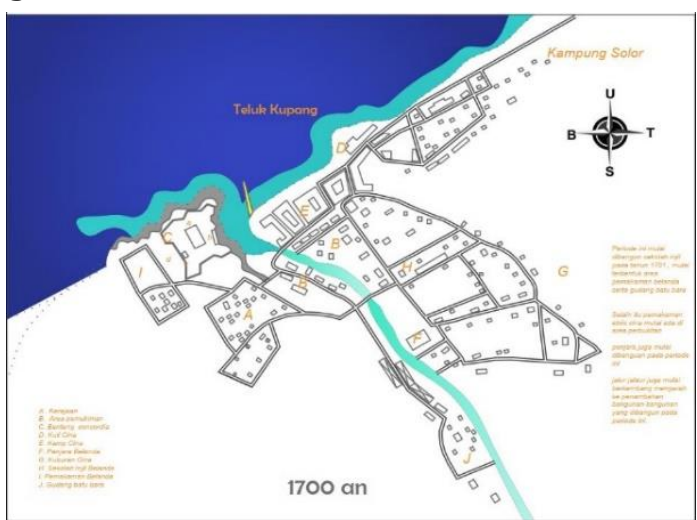

Gambar 9. Peta kawasan Kota Lama Kupang abad ke 17(analisis peneliti, 2019)

\section{Temuan hasil analisis sinkronik perkembangan kawasan Kota Lama Kupang periode abad ke 17}

Berdasarkan hasil analisis sinkronik perkembangan kawasan Kota Lama Kupang maka didapatkan temuan sebagai berikut: (1) Pembangunan penjara, gudang batu bara, perkuburan dan sekolah injil. (2) Penambahan elemen jaringan jalan menuju arah Selatan daerah perbukitan serta penambahan blok-blok jalan di daerah perbukitan

Periode Abad ke 18

Gambar 10 memperlihatkan perkembangan Kota Lama Kupang pada periode abad ke 18.

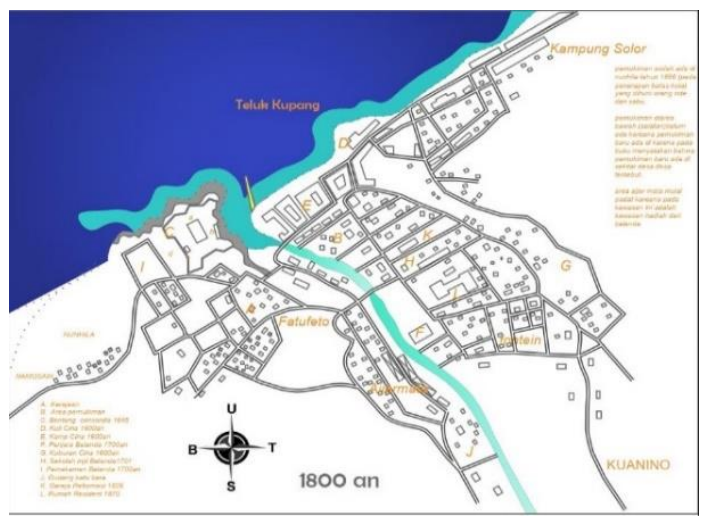

Gambar 10. Peta kawasan Kota Lama Kupang abad ke 18 (analisis peneliti, 2019)

\section{Temuan hasil analisis sinkronik} perkembangan kawasan Kota Lama Kupang periode abad ke 18

Berdasarkan hasil analisis sinkronik perkembangan kawasan Kota Lama Kupang maka didapatkan temuan sebagai berikut. (1) Belanda membuat daerah penyangga di luar benteng Concordia bagi anggota pasukan untuk bercocok tanam sendiri dan disediakan pemukiman untuk memperluas wilayah dengan mengatur pemukiman berdasarkan etnis. (2) Belanda menetapkan batas-batas kota untuk menyangga kawasan Kota Lama Kupang. (3) Perluasan elemen jaringan jalan menuju arah selatan kuanino, ke arah Timur Kampung Solor sampai Pasir Panjang depan asrama Brimob, serta ke arah Barat sampai Namosain.

Periode Abad ke 19 (Pra Kemerdekaan Indonesia)

Periode awal abad 19 tahun 1900, berdasarkan sejarah kawasan Kota Lama Kupang, perkembangan kawasan semakin meningkat dari aspek ekonomi yaitu dengan bertambahnya etnis Cina, sehingga munculnya permukiman perdagangan yang cukup padat di area Teluk Kupang karena dibangunnya pertokoan di area Kota Lama Kupang.

Pertumbuhan permukiman di kawasan Kota Lama Kupang diawal abad 19 berupa area kawasan yang semakin padat ialah dari daerah sekitaran benteng 
sampai area sekitaran pelabuhan Teluk Kupang. Kemudian pertumbuhan penduduk di daerah luar kawasan Kota Lama juga mulai meningkat dan memengaruhi perluasan permukiman ke arah Timur, Barat, dan Selatan di luar kawasan Kota Lama Kupang. Kawasan Kota Lama Kupang menjadi salah satu kawasan yang padat sampai tidak mempunyai ruang untuk memperluas wilayah pemukiman. Hal ini karena meningkatnya pertumbuhan penduduk mulai tahun 1825 (Departemen Pendidikan dan Kebudayaan Republik Indonesia, 1983) .

Berdasarkan peta kawasan tahun 1900 terdapat pembangunan berupa Masjid di area Selatan dekat Desa Fontein serta terdapat blok-blok yang mulai muncul di pemukiman masyarakat dan pusat pemerintahan Belanda (Lihat gambar 11).

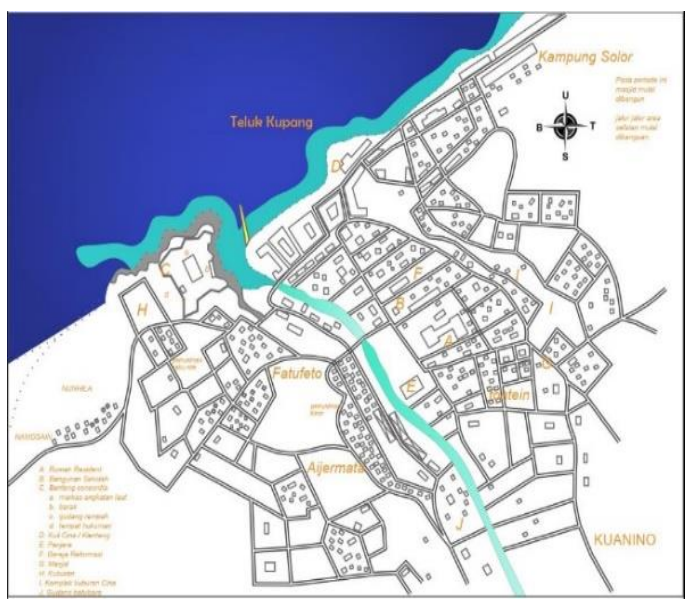

Gambar 11. Peta kawasan Kota Lama Kupang abad ke 19 sebelum kemerdekaan Indonesia (analisis peneliti, 2019)

\section{Periode abad ke 19 (Pasca Kemerdekaan Indonesia)}

Pada tahun 1947 setelah kemerdekaan, berdasarkan sejarah, jika dilihat pada peta tahun 1947 terdapat perkembangan jaringan jalan dan blok-blok jalan di dalam pemukiman. Hal ini dikarenakan periode sebelumnya jaringan jalan dan blok-blok tersebut belum diaspal atau dikeraskan. Jalan yang diaspal pada periode sebelumnya hanya jalan umum yang menghubungkan Kota Kupang dengan Desa Camplong (wilayah Kabupaten Kupang). Kemudian, setelah perang dunia kedua lokasi pasar yang terletak di area Teluk Kupang dibangun toko-toko oleh etnis Cina, sedangkan pasar tersebut dipindahkan ke arah Selatan di terminal angkot sekarang (2019) (Soh \& Damajanti, 2008) (Lihat gambar 12).

Temuan hasil analisis sinkronik perkembangan kawasan Kota Lama Kupang periode abad ke 19

Berdasarkan hasil analisis sinkronik perkembangan kawasan Kota Lama Kupang maka didapatkan temuan sebagai berikut.

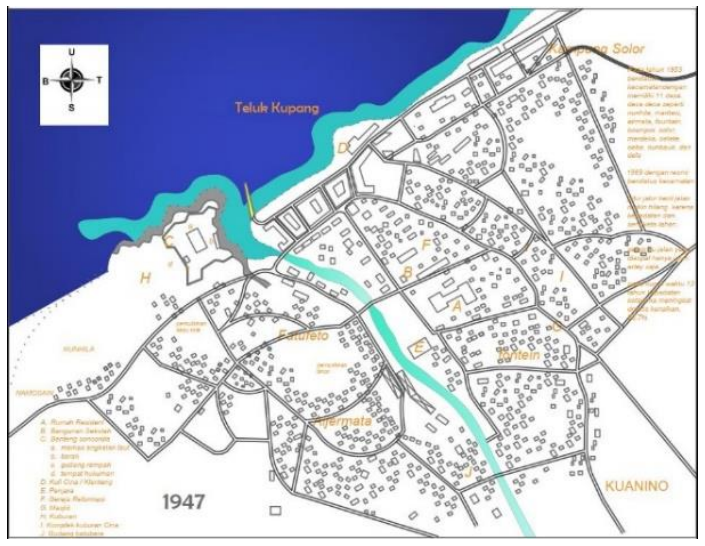

Gambar 12. Peta kawasan Kota Lama Kupang tahun 1947, periode setelah Indonesia merdeka (analisis peneliti, 2019)

(1) Perluasan pemukiman ke arah Barat, Timur dan Selatan hingga keluar dari kawasan Kota Lama Kupang. (2) Pada Tahun 1900 terdapat penambahan elemen kota pada kawasan Kota Lama Kupang berupa pembangunan Masjid dan penambahan blok-blok di setiap pemukiman. (3) Setelah Kemerdekaan Indonesia tahun 1947 terjadi perkembangan terhadap elemen kawasan yakni perkerasan atau pengaspalan jaringan jalan dan blok pada pemukiman. (4) Tahun 1953 adanya kebijakan politik yang berpengaruh terhadap status kawasan yaitu Kupang disamakan dengan 
kecamatan sehingga status kawasan berubah menjadi desa yang digabungkan dengan Desa Bonipoi. (5) Tahun 1969 adanya kebijakan politik yang berpengaruh terhadap status kawasan yaitu Kupang dengan resmi berstatus sebagai kecamatan sehingga status kawasan Kota Lama Kupang berdiri sendiri menjadi Desa Lahi Lai Bissin Kopan. (6) Tahun 1978 adanya kebijakan politik yaitu Kecamatan Kupang dengan resmi berstatus sebagai Kota Administratif (Kotip) dan status kawasan Kota Lama Kupang masih menjadi Desa Lahi Lai Bissin Kopan. (7) Tahun 1996 adanya kebijakan politik yang berpengaruh terhada status kawasan yaitu Kupang dengan resmi berstatus sebagai Kotamadya sehingga status kawasan Kota Lama menjadi Keluarahan Lahi Lai Bissin Kopan. (8) Tahun 1999 adanya kebijakan politik yaitu Kotamadya Kupang dengan resmi berstatus sebagai Kota Kupang dan status kawasan masih sama dengan periode sebelumnya yakni Keluarahan Lahi Lai Bissin Kopan.

\section{Periode abad ke 21}

Periode abad ke 21 tahun 2019 kondisi fisik dari bangunan-bangunan bekas Kolonial seperti benteng "Fort Concordia" berubah fungsi menjadi benteng Tentara Nasional Indonesia (TNI) angkatan udara. Kemudian lelabuhan lama Teluk Kupang yang dulunya sebagai akses laut perdagangan kini sudah dialih fungsikan sebagai tempat berlabuh kapal-kapal dari luar negeri yang berwisata di Kota Kupang dan area sekitaran Teluk Kupang dijadikan sebagai tempat berjualan pedagang kaki lima (PKL), bar, dan penginapan. Bekas rumah Residen Belanda dialih fungsikan menjadi Kantor Bupati, kemudian dipindahkan ke luar Kota Kupang karena terjadi perluasan wilayah, oleh karena itu bekas rumah Residen Belanda tersebut difungsikan bagi Perguruan Tinggi dan
Sekolah Menegah yang ada di Kota Kupang sebagai wadah sementara untuk kegiatan belajar. Selain itu, beberapa bekas bangunan serta perkuburan Kolonial seperti penjara lama, kantor Asisten Residen, kantor Bea Cukai, perkuburan Belanda, perkuburan etnis Cina sudah tidak difungsikan lagi, hanya beberapa bangunan Kolonial yang bertahan seperti Gereja Reformasi, Masjid, Kuil Cina yang sudah direnovasi (Lihat gambar 13).

Perkembangan elemen fisik berupa jalan di abad ke 21 yaitu tiga jalan umum ke arah Timur, Selatan, Barat dan jalan kolektor yang membentang pada area Kampung Solor masih sama dengan periode-periode sebelumnya,

Pemukiman masyarakat di periode abad ke 21 sudah sangat padat dan tidak terdapat ruang kosong untuk perluasan kawasan. Kemudian, pertokoan yang berada di kawasan Kota Lama Kupang sudah tidak layak bahkan dan ada yang roboh akibat kekuatan struktur mulai rapuh.

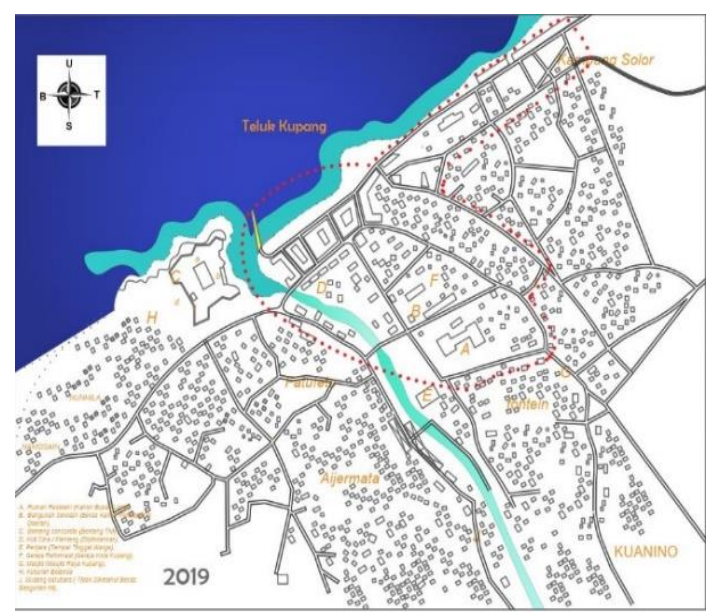

Gambar 13. Peta kawasan Kota Lama Kupang tahun 2019 (analisis peneliti, 2019)

\section{Temuan hasil analisis sinkronik perkembangan kawasan Kota Lama Kupang periode abad ke 21}

Berdasarkan hasil analisis sinkronik perkembangan kawasan kota lama Kupang maka didapatkan temuan sebagai berikut. (1) Adanya kebijakan politik pada 
tahun 2010 terjadi pemekaran kecamatan di Kota Kupang, sehingga dibentuk Kecamatan Kota Lama sebagai pemekaran dari Kecamatan Kelapa Lima berdasarkan Peraturan Daerah Pemerintah Kota Kupang Nomor 04 tahun 2010. Status kawasan Kota Lama Kupang masih sama seperti periode sebelumnya yaitu Kelurahan Lahi Lai Bissin Kopan. (2) Penetapan Rencana Tata Ruang Wilayah Kota Kupang 2011-2031 yang mengatur status Kelurahan Lahi Lai Bissin Kopan sebagai kawasan perdagangan dan jasa dengan perpaduan kawasan peribadatan, perkantoran pemerintahan serta pariwisata. (3) Bangunan bekas peninggalan Belanda yang berada di kawasan Kota Lama Kupang berupa benteng Concordia, rumah Residen, kuil Cina, Gereja Reformasi, Masjid, yang masih berfungsi dan kantor Asisten Residen, kantor Bea Cukai, penjara lama, sekolah, perkuburuan Belanda, dan perkuburan etnis Cina sudah tidak difungsikan lagi. Kemudian, pelabuhan laut sudah dialih fungsikan sebagai tempat berlabuh bagi kapal-kapal dari luar negeri yang berwisata di Kota Kupang. (4) Perkembangan elemen jaringan jalan masih seperti periode sebelumnya yaitu membentang ke arah Timur (Kampung Solor), Barat (Namosain) dan Selatan (Kuanino). (5) Pemukiman masyarakat sudah padat dan kondisi fisik bangunan pertokoan mempunyai struktur yang sudah mulai rapuh serta beberapa pertokoan yang dibangun di atas karang tepian laut.

\section{Analisis diakronik kawasan Kota Lama} Kupang periode abad ke 15 - 21

Analisis perubahan dan perbandingan morfologi kawasan Kota Lama Kupang berdasarkan periode waktu, yakni abad 15 sampai abad ke 21 (2019). Untuk melihat perubahan-perubahan yang terjadi pada kawasan Kota Lama Kupang serta membandingkan perubahan tersebut dengan periode sebelumnya berdasarkan sejarah dan dari hasil analisis sinkronik.

\section{Temuan hasil analisis diakronik kawasan Kota Lama Kupang periode abad ke 15 dan 16}

Perubahan dan perbandingan antara periode abad ke 15 dan 16 yakni perkembangan yang berpengaruh pada kawasan Kota Lama Kupang terjadi saat masuknya kedua bangsa asing Portugis dan Belanda, kemudian ditambah dengan masuknya etnis China. Hal ini dapat dilihat pada periode abad ke 16, adanya penambahan elemen jaringan jalan yang membentang ke arah Timur (Kampung Solor), Barat, Selatan serta penambahan pemukiman oleh Belanda untuk sekutusekutunya, dan pemukiman bagi etnis Cina, sehingga terdapat pemukiman Cina di area Teluk Kupang (Lihat gambar 14).

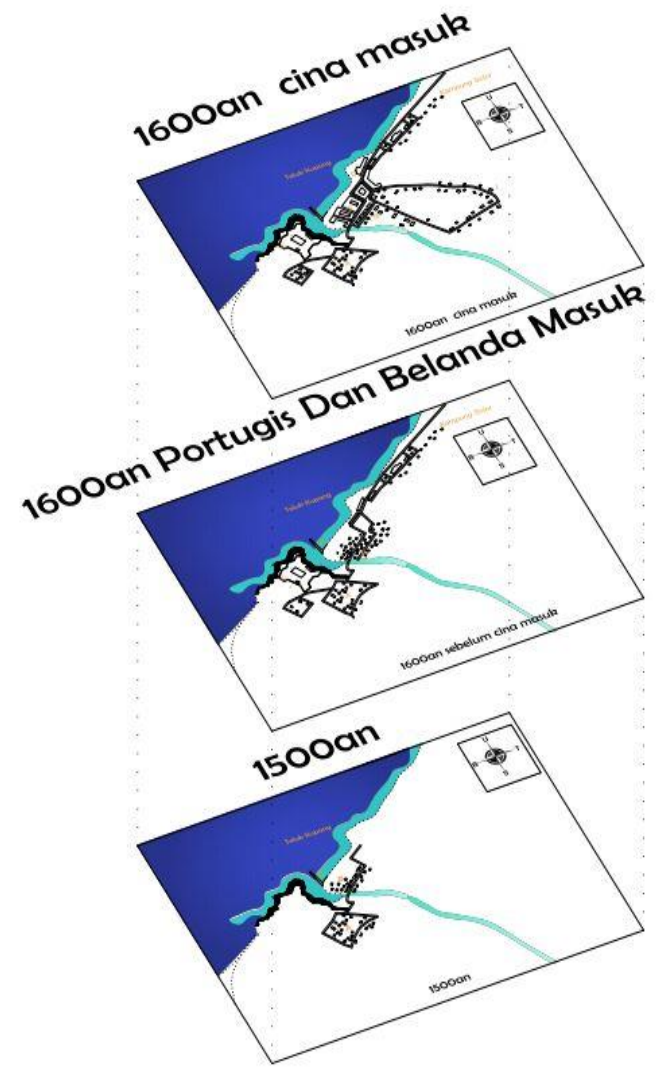

Gambar 14. Peta perubahan dan perbandingan morfologi kawasan Kota Lama Kupang abad 15 dan 16 (analisis peneliti, 2019) 


\section{Temuan hasil analisis diakronik kawasan Kota Lama Kupang periode abad ke 17 dan 18}

Perbandingan antara kedua periode ini yaitu pada abad ke 17 kawasan Kota Lama Kiupang belum mempunyai batas-batas kota sehingga kondisi perubahan kawasan tidak terlalu berkembang. Periode abad ke 18 terlihat perkembangan yang berpengaruh terhadap kondisi fisik kawasan yaitu dengan penetapan batasbatas kota oleh Belanda, sehingga bertambahnya jaringan jalan dan pemukiman masyarakat. Perluasan jaringan jalan berdasarkan batas-batas kota yang sudah ditetapkan yaitu $\mathrm{Km} 0$ (depan rumah residen) ditarik $1 \frac{1}{2} \mathrm{~km}$ ke arah Timur daerah Pasir Panjang, ke arah Barat daerah Namosain, dan ke arah Selatan ialah Kuanino. Kemudian pemukiman masyarakat yang diatur berdasarkan etnis (Lihat gambar 15).

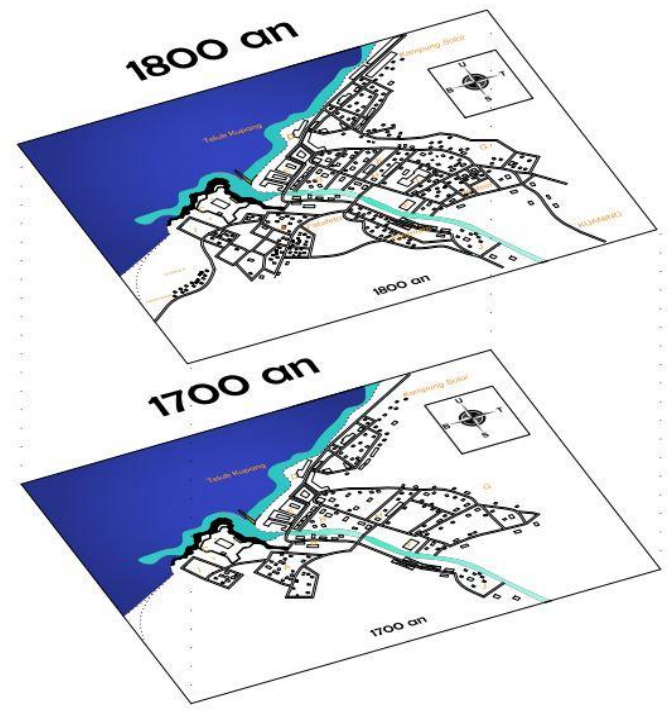

Gambar 15. Peta perubahan dan perbandingan morfologi kawasan Kota Lama Kupang abad 17 dan 18 (analisis peneliti, 2019)

\section{Temuan hasil analisis diakronik kawasan Kot a Lama Kupang periode abad ke 19 dan 21}

Perbandingan periode abad ke 19 dan 21 terdapat perubahan yang cukup drastis pada abad ke 21. Ditinjau dari perkembangan blok-blok jaringan jalan dimana pada tahun 1900 terlihat cukup banyak blok-blok di setiap pemukiman sampai pada tahun 1947 mulai hilang karena dalam penjelasannya tahun 1900 jalan yang diaspal hanyalah jalan umum. Kemudian blok-blok tersebut merupakan jalan setapak atau jalan kuda yang hanya bisa dilalui oleh satu atau dua orang serta diaspal pada tahun 1947. Periode abad ke 21 jalan umum tidak terdapat perubahan, masih seperti periode sebelumnya 1947 dan blok-blok pada pemukiman hampir seluruhnya hilang, hanya terdapat sebagian yang masih ada. Ditinjau dari perubahan letak bangunan-bangunan masih seperti periode sebelumnya yaitu letak toko milik etnis Cina yang mulai dibangun pada tahun 1947 masih sama, kemudian letak bangunan-bangunan peninggalan Belanda letaknya masih sama hanya beberapa bangunan dialih fungsikan menjadi kantor dan beberapa lainnya tidak difungsikan lagi. Kemudian berdasarkan RTRW Kota Kupang tahun 2011-2031 penggunaan lahan dikawasan Kota Lama Kupang menjadi kawasan perdagangan dan jasa (Lihat gambar 16).

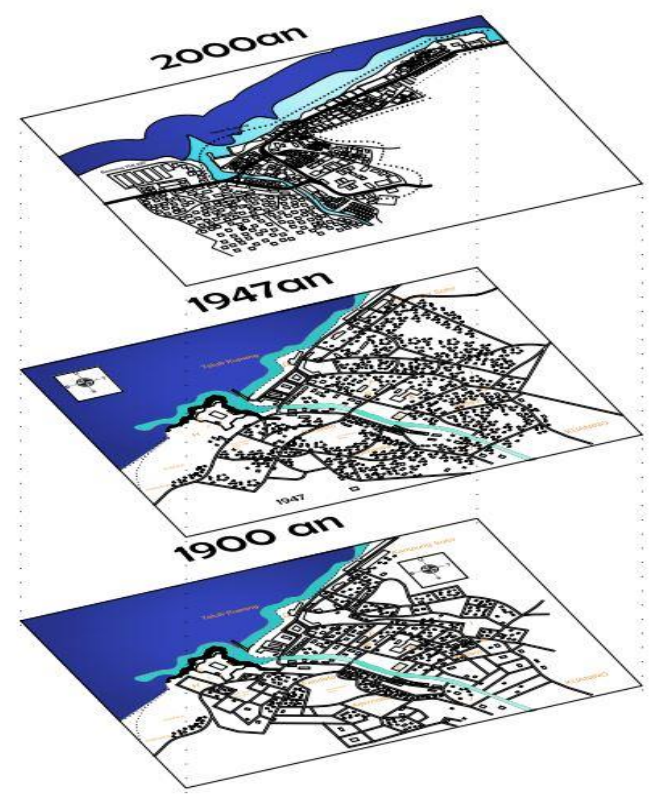

Gambar 16. Peta perubahan dan perbandingan morfologi kawasan Kota Lama Kupang abad 19 dan 21 (analisis peneliti, 2019) 


\section{Kesimpulan}

Berdasarkan hasil analisis sinkronik perkembangan dan analisis diakronik perbandingan morfologi kawasan Kota Lama Kupang periode abad 15 hingga abad ke 21 dapat disimpulkan bahwa generator penggerak utama perkembangan kawasan Kota Lama Kupang pada periode abad ke 15 ialah (1) masuknya Raja Helong yang menguasai kawasan; (2) kawasan Kota Lama Kupang menjadi salah satu kota bandar yang ada di Pulau Timor sehingga menjadi pintu masuk bagi para bangsa Portugis, Belanda, Cina, dan orang dari luar kota untuk menguasai maupun berdagang; (3) Area Teluk Kupang menjadi tempat kegiatan perdagangan dari periode abad ke 15 sampai pada periode abad ke 21 .

\section{Pernyataan penulis}

Dengan ini penulis menyatakan bahwa penelitian ini terbebas dari konflik kepentingan dengan pihak manapun

\section{Ucapan terimakasih}

Penulis mengucapkan terimakasih kepada Universitas Atma Jaya Yogyakarta khususnya Program Studi Pascasarjana Arsitektur dan Universitas Katolik Widya Mandira, serta semua pihak yang telah mendukung kegiatan penelitian ini.

\section{Referensi}

Ardhiansyah, N., Widyastuti, D. A. R., \& Septiari, E. D. (2019). Perubahan tata guna lahan kampung Prawirotaman kota Yogyakarta sebagai dampak keberadaan kawasan komersial. ARTEKS: Jurnal Teknik Arsitektur, 3(2), 131138.

https://doi.org/10.30822/arteks. v3i2.66

Bakosurtanal. (1998). Kupang D M 16,28. Leiden Universities Librarie | Digital Collections. http://hdl.handle.net/1887.1/ite $\mathrm{m}: 2407792$

Bintarto, R. (1977). Pengantar geografi kota. Spring.

BPS Kota Kupang. (2014). Kota Kupang Dalam Angka 2014. https://kupangkota.bps.go.id/pub lication/2014/08/15/58376aab8 84d1a8fea6071e9/kota-kupangdalam-angka-2014.html

Branch, M. C. (1995). Perencanaan kota komprehensif: Pengantar \& penjelasan (B. H. Wibisono \& A. Djunaedi, Trans.; Terjemahan). Gadjah Mada University Press.

Departemen Pendidikan dan Kebudayaan Republik Indonesia. (1983). Sejarah Sosial di Daerah Nusa Tenggara Timur. Departemen Pendidikan dan Kebudayaan Republik Indonesia.

Fox, J. J. (1997). Harvest of the Palm: Harvard University Press.

J Detaq. (1971). Memperkenalkan Kota Koepang.

jejakembara. (2014, October 10). Kawasan kota lama kupang. Baomong Kupang.

https://baomongkupang.wordpre ss.com/2014/10/10/kawasankota-lama-kupang/

Lake, R. C., Mberu, Y. B., Diaz, A., Lake, R. C., Mberu, Y. B., \& Diaz, A. (2019). Elemen-Elemen Pembentuk Sistem Kota-Lama Kupang. Jurnal Arsitektur Komposisi, 12(3), 257269.

https://doi.org/10.24002/jars.v1 2i3.2235

Luitnan, I. A. (2012). Koepang tempo doeloe: Kisah eksodus etnik Helong dari Nusa Ina, penghuni pemula Kaisalun, Bunibaun, Kota Kupang, 
Nusa Tenggara Timur. Penerbit Ruas.

Rossi, A. (1984). The Architecture of the City. MIT Press.

Setiadi, A. (2018). Strategi implementasi konsep waterfront city kota Kupang. ARTEKS: Jurnal Teknik Arsitektur, 3(1), 1-10. https://doi.org/10.30822/arteks. v3i1.49

Situmorang, N. (2018). Citra Kota Kupang dalam Arsip

(https://anri.go.id/sekitararsip/arsip-statis/naskahsumber). Citra Kota Kupanga dalam Arsip; Arsip Nasioanal Republik Indonesia. https://anri.go.id/download/nask ah-sumber-arsip-citra-daerahkota-kupang-dalam-arsip1586396164

Soh, A. Zacharias., \& Damajanti, M. N. (2008). Timor Kupang: Dahulu dan sekarang. Yayasan Kelompok Penggerak Aktivitas Kebudayaan. http://repository.petra.ac.id/171 56/1/Publikasi1_01026_1985.pdf

Whitehand, J. W. R. (1977). The Basis for an Historico-Geographical Theory of Urban Form. Transactions of the Institute of British Geographers, 2(3), 400-416. https://doi.org/10.2307/621839

Yunus, H. S. (2008). Dinamika Wilayah Peri-Urban: Determinan Masa Depan Kota. Pustaka Pelajar.

Zahnd, M. (1999). Perancangan Kota secara Terpadu: Teori Perancangan Kota dan Penerapannya (Vol. 2). Kanisius.

\section{Kontribusi Penulis}

Rudini A. R. B. Lamahoda berkontribusi dalam penyusunan konsep penelitian, metodologi, investigasi, analisis data, visualisasi serta penyusunan draft artikel dan revisi.

Amos Setiadi berkontribusi dalam metodologi. supervisi dan validasi

Reginaldo Christophori Lake berkontribusi dalam metodologi. supervisi dan validasi

Ricky Samara berkontribusi dalam metodologi. supervisi dan validasi 